Author version: J. Environ. Qual., vol.39; 2010; 1507-1516

\title{
Denitrification: an important pathway for nitrous oxide production in tropical mangrove sediments (Goa, India)
}

Sheryl Oliveira Fernandes and P.A. Loka Bharathi ${ }^{*}$, NIO, India

Patricia C. Bonin and Valérie D. Michotey, LMGEM, Marseille

\begin{abstract}
Net nitrous oxide production and denitrification activity were measured in two mangrove ecosystems of Goa, India. The relatively pristine site Tuvem was compared to Divar which is prone to high nutrient input. Stratified sampling at $2 \mathrm{~cm}$ intervals within the $0-10 \mathrm{~cm}$ depth range showed that $\mathrm{N}_{2} \mathrm{O}$ production at both the locations decreased with depth. Elevated denitrification activity at Divar resulted in maximum production of up to 1.95 nmol $\mathrm{N}_{2} \mathrm{O}-\mathrm{N} \mathrm{g}^{-1} \mathrm{~h}^{-1}$ at 2-4 $\mathrm{cm}$ which was 3 times higher than at Tuvem. Detailed investigations to understand the major pathway contributing to nitrous oxide production carried out at Tuvem showed that incomplete denitrification was responsible for up to $43-93 \%$ of $\mathrm{N}_{2} \mathrm{O}$ production. $\mathrm{N}_{2} \mathrm{O}$ production rates closely correlated to nitrite concentration $(\mathrm{n}=15 ; \mathrm{r}=-0.47 ; \mathrm{p}<0.05)$ and denitrifier abundance $(\mathrm{r}=0.55 ; \mathrm{p}<0.05)$ suggesting that nitrite utilisation by microbial activity leads to $\mathrm{N}_{2} \mathrm{O}$ production. Nitrous oxide production through nitrification was below detection affirming that denitrification is the major pathway responsible for production of the greenhouse gas. Net $\mathrm{N}_{2} \mathrm{O}$ production in these mangrove systems are comparatively higher than those reported from other natural estuarine sediments and therefore warrant mitigation measures.
\end{abstract}

Sheryl Oliveira Fernandes and P.A. Loka Bharathi, Marine microbiology laboratory, National Institute of Oceanography, CSIR, Dona Paula, Goa, India - 403004.

Patricia C. Bonin and Valérie D. Michotey, Laboratoire de Microbiologie, de Géochimie et d'Ecologie Marines, CNRS-UMR 6117, Centre d'Océanologie de Marseille, Campus de Luminy, Case 901, 13288 Marseille Cedex 9, France

Abbreviations: DNT, denitrification activity; ${ }^{\mathrm{D}} \mathrm{N}_{2} \mathrm{O}$, incomplete denitrification; ${ }^{\mathrm{I}} \mathrm{N}_{2} \mathrm{O}$, percentage of $\mathrm{N}_{2} \mathrm{O}$ through incomplete denitrification; MPN, most probable number; ${ }^{\mathrm{N}} \mathrm{N}_{2} \mathrm{O}$, nitrous oxide produced through nitrification; NPL, National Physical Laboratory; PCA, Principal component analysis; TOC, total organic carbon.

\footnotetext{
* Corresponding author (1oka@nio.org)
} 


\section{Introduction}

The marine environment is recognized as a net source of nitrous oxide $\left(\mathrm{N}_{2} \mathrm{O}\right)$ to the atmosphere (Corredor et al., 1999). Estuaries and coastal regions account for approximately $60 \%$ of the total oceanic $\mathrm{N}_{2} \mathrm{O}$ flux (Bange et al., 1996). The $\mathrm{N}_{2} \mathrm{O}$ molecule is a precursor to compounds involved in the destruction of the stratospheric ozone layer (Yamagishi et al., 2007) which protects Earth from harmful ultraviolet radiation. Since $\sim 1750$ onwards, industrialisation has increased the global atmospheric $\mathrm{N}_{2} \mathrm{O}$ concentration from $\sim 270$ to $319 \mu \mathrm{L} \mathrm{L}^{-1}$ (IPCC, 2007). Though $\mathrm{N}_{2} \mathrm{O}$ is responsible for 5-6\% of the greenhouse effect (Houghton et al., 1996), it's lifetime of about 114 years makes the global warming potential of this biogenic gas 298 times greater than that of $\mathrm{CO}_{2}$ over a 100 -year time frame (Forster et al., 2007). Nitrous oxide is produced as a by-product during several microbiological processes including nitrification, denitrification and dissimilatory nitrate reduction to ammonium (De Wilde and De Bie, 2000). However, denitrification and chemolithotrophic nitrification appear to be the main biological sources of $\mathrm{N}_{2} \mathrm{O}$ emission in natural systems (Bremner and Blackmer, 1978; Firestone and Davidson, 1989; Bonin et al., 2002).

In ecosystems with high inputs of nitrogen $(\mathrm{N})$ such as estuaries, denitrification mediates reduction of $\mathrm{N}$ loadings and therefore contributes to control of eutrophication (Nogales et al., 2002). Mangroves ecosystems constitute nearly $75 \%$ of tidal vegetation in tropical regions (Alongi et al., 1989) and they play an important role in the biogeochemical cycles of coastal and marine ecosystems (Thorsten and José, 2001). The $\mathrm{N}$ cycle within mangrove forests is mediated predominantly by microbial rather than chemical processes (Alongi et al., 1992). Inorganic $\mathrm{N}$ and other parameters important for $\mathrm{N}$ turnover can fluctuate widely due to the position of mangroves in the intertidal zone (Meyer et al., 2008). Anthropogenic inputs such as like effluents from sewage treatment plants (Corredor and Morell, 1994) increase the rate of $\mathrm{N}$ loading to mangroves (Muñoz-Hincapié et al., 2002). They function as efficient buffer zones mitigating large amounts of nutrients (Corredor and Morell, 1994) in the estuarine system and reduce water pollution. Chiu et al. (2004) state that as much as $55 \%$ of the $\mathrm{N}$ loss in mangrove sediments occurs through the denitrification pathway. Earlier studies have recorded a substantial benthic flux of $\mathrm{N}_{2} \mathrm{O}$ in mangroves (Corredor et al., 1999; Muñoz-Hincapié et al. 2002; Kreuzwieser et al., 2003). Mangrove sediments are largely anaerobic and rich in organic matter providing favourable conditions for denitrification. However, redox processes in the $\mathrm{N}$ cycle operate in tandem stressing the importance of considering total $\mathrm{N}_{2} \mathrm{O}$ production rates from nitrification and 
denitrification (Meyer et al., 2008). Further, $\mathrm{N}_{2} \mathrm{O}$ production is dependant on a number of environmental factors such as inorganic $\mathrm{N}$ concentrations (Dong et al., 2002), sediment redox potential (Van Cleemput and Samater, 1996) and organic carbon availability (Rosswell et al., 1989). Therefore, assessment of environmental parameters and their inter-relationships with net $\mathrm{N}_{2} \mathrm{O}$ production in mangrove sediments is crucial in determining the key parameters governing its formation.

In the Indian Ocean region, high $\mathrm{N}_{2} \mathrm{O}$ emission has so far been reported within the oxygen minimum zones in the Arabian Sea (Naqvi et al., 2000; Bange et al., 2001). Recently, investigations by Krithika et al. (2008) in a South Indian mangrove system have shown that the benthic $\mathrm{N}_{2} \mathrm{O}$ flux varies between 0.41 and $0.77 \mu \mathrm{mol} \mathrm{m} \mathrm{m}^{-2} \mathrm{~h}^{-1}$ indicating that these wetlands are significant contributors of the radiative gas to the atmosphere. However, little is known about the net production or origin of $\mathrm{N}_{2} \mathrm{O}$ in these environments. In the present study, we quantified down-core variation in denitrification activity and net $\mathrm{N}_{2} \mathrm{O}$ production in two mangrove ecosystems of Goa, India - one relatively pristine and the other influenced by extraneous nutrient input. Detailed studies to assess the major pathway for $\mathrm{N}_{2} \mathrm{O}$ production and environmental factors responsible for its generation have been restricted to the relatively undisturbed site. Since there is growing concern over the role of mangrove ecosystems with respect to increased $\mathrm{N}_{2} \mathrm{O}$ fluxes to the atmosphere, the study would enhance our knowledge on the contribution of the $\mathrm{N}$ cycle processes in $\mathrm{N}_{2} \mathrm{O}$ production. In addition, our study would help initiate the formulation of mitigatory measures to minimize $\mathrm{N}_{2} \mathrm{O}$ production and its emission from estuarine zones of the Indian Ocean region.

\section{Materials and methods}

\section{Study area and sampling}

Investigations were carried out at mangrove forests located at Tuvem and Divar along the rivers Chapora and Mandovi respectively, in Goa on the west coast of India (Fig. 1). The site at Tuvem $\left(15^{\circ} 39^{\prime} 94^{\prime \prime} \mathrm{N}\right.$ and $\left.73^{\circ} 47^{\prime} 65^{\prime \prime} \mathrm{E}\right)$ is set amidst coconut, cashew and banana plantations and is comparatively less influenced by anthropogenic activities. The Divar mangrove ecosystem $\left(15^{\circ} 30^{\prime} 35^{\prime \prime} \mathrm{N}\right.$ and $73^{\circ} 52^{\prime} 63^{\prime \prime} \mathrm{E}$ ) is separated from the mainland by the river Mandovi. The Mandovi is prone to high nutrient concentrations especially during the monsoon season which has been attributed to riverine and land runoff (Divya et al., 2009) and anthropogenic sources (De Souza, 1983). Approximately 10 $\mathrm{Mg} /$ month of $\mathrm{NH}_{4} \mathrm{NO}_{3}$ is used as explosive in ferromanganese mining operations upstream of the 
Mandovi (De Sousa, 1999). Iron ore beneficiation plants situated on the riverbanks carry out treatment and up-gradation of low grade ore fines. These plants use river water to wash the iron ore and discharge effluents directly into the aquatic system. This wastewater contains $\sim 80 \mu \mathrm{mol} \mathrm{NO}_{3}-\mathrm{N} \mathrm{L}^{-1}$ forming a major source of the nutrient to the estuary (De Sousa, 1999). Annual variation of $\mathrm{NO}_{3}{ }^{-} \mathrm{N}^{-}$concentrations along the Mandovi estuary has been reported by Divya et al., (2009). Further, Krishnan et al. (2007) have shown that the Divar mangrove sediments are also enriched with metals (primarily Fe and Mn) as a result of ferromanganese mining upstream of the Mandovi. These metals mainly Fe have been shown to influence $\mathrm{N}$ transformations (Krishnan and Loka Bharathi, 2009).

Sediment samples were collected at low tide during January 2008 (post-monsoon season) using hand-held PVC push cores (inner diameter $7.5 \mathrm{~cm}, 15 \mathrm{~cm}$ length). The cores were immediately capped at both ends and transported to the laboratory in an ice box. Cores for pore water nutrient and denitrification rate measurements were maintained at $4^{\circ} \mathrm{C}$ until analysis. Water from the sampling sites was collected in carbuoys for media preparation.

\section{Physico-chemical parameters}

Hydrogen ion concentration $(\mathrm{pH})$ was measured upon sample arrival at the laboratory using an Orion 4-Star Plus benchtop pH/ISE meter (Thermo Fisher Scientific Inc., USA). Sediment oxidationreduction potential (Eh) was measured using an Orion platinum redox in combination with a $\mathrm{Ag} / \mathrm{AgCl} \mathrm{Cl}_{2}$ reference electrode (Thermo Fisher Scientific Inc., USA).

For nutrient analyses, triplicate sub-samples from sediment cores were taken at $2 \mathrm{~cm}$ increments from 0 to $10 \mathrm{~cm}$ depth by careful sectioning of sediment. Each section $(7.5 \mathrm{~cm}$ diameter and $2 \mathrm{~cm}$ thick) was transferred to $100 \mathrm{~mL}$ of sterile saline $(0.85 \% \mathrm{NaCl})$ and gently homogenized using a glass rod. The slurry was centrifuged at $4^{\circ} \mathrm{C}$ for 10 minutes at $5000 \mathrm{rpm}$ (x $1803 \mathrm{~g}$ ) with a high speed cooling centrifuge (Model CPR-24; Remi Instrument Ltd., India). A low spin speed was maintained during centrifugation to ensure minimal change in nutrient concentrations due to lysis of benthic infauna. The supernatant was filtered through a $0.2 \mu \mathrm{m}$ filter and stored at $-20^{\circ} \mathrm{C}$ until analysis. Ammonium, $\mathrm{NO}_{2}^{-}-\mathrm{N}$ and $\mathrm{NO}_{3}{ }^{-}-\mathrm{N}$ were measured colorimetrically (UV mini 1240 spectrophotometer; Shimadzu Corp., Japan) as described by Koroleff (1969), Bendschneider and Robinson (1952) and Wood et al. (1967). The weight of the sediment used in the extraction was estimated by drying the wet samples at $60^{\circ} \mathrm{C}$ for 48 
hours. Total organic carbon (TOC) was determined by wet oxidation method with a precision of $0.01 \%$ (El Wakeel and Riley, 1957).

\section{Denitrification rate, net nitrous oxide production and its origin}

Sediment cores were demarcated into five sections $(0-2,2-4,4-6,6-8$ and 8-10 cm). Then $1 \mathrm{~mL}$ of sediment was extruded from each section using a syringe core and transferred aseptically to sterile 20 $\mathrm{mL}$ headspace vials. Three $\mathrm{mL}$ of sterilized ambient sea water from the sampling site (containing 4.5

$\mu$ mol $\left.\mathrm{NO}_{3}{ }^{-}-\mathrm{N} \mathrm{L}^{-1}\right)$ was added. Further, sample preparations were ammended with chloramphenicol $(1 \mathrm{~g}$ $\mathrm{L}^{-1}$ ) to prevent de novo enzyme synthesis during the incubations (Bonin et al., 2002). No additional $\mathrm{C}$ or $\mathrm{NO}_{3}{ }^{-}-\mathrm{N}$ was added as substrate. The vials were capped with butyl stoppers, sealed with Al crimps and then briefly vortexed to form a slurry.

Denitrification activity (DNT) was measured by the acetylene inhibition technique based on the inhibition of the conversion of $\mathrm{N}_{2} \mathrm{O}$ to $\mathrm{N}_{2}$ (Sørensen, 1978). Over short incubation intervals, it is a costeffective method for estimating denitrification and rate estimates are comparable to those obtained by the membrane inlet mass spectrometry (Bernot et al., 2003). Thus to measure DNT, some of the vials were made anaerobic by flushing with $\mathrm{N}_{2}$ for $15 \mathrm{~min}$. The headspace over these slurries was ammended with acetylene at $20 \mathrm{kPa}$ (Bonin et al., 2002) and the tubes were briefly vortexed.

To determine net $\mathrm{N}_{2} \mathrm{O}$ production, aerobic conditions were maintained in the vials and no acetylene was added to the headspace. However, to measure $\mathrm{N}_{2} \mathrm{O}$ produced by denitrifiers $\left({ }^{\mathrm{D}} \mathrm{N}_{2} \mathrm{O}\right)$, aerobic conditions were maintained and the headspace was adjusted to an acetylene concentration of 10 $\mathrm{Pa}$ to inhibit nitrification (Berg et al., 1982; Bonin et al., 2002). Triplicate measurements were performed at each depth and the vials were incubated in the dark for 0.5, 1.0, 1.5, 2.0, 2.5 and 3.0 hours. Following incubation, each vial was treated with $0.1 \mathrm{~mL}$ of 1 molar $\mathrm{HgCl}_{2}$ solution and vigorously shaken for $2 \mathrm{~min}$ to stop the reaction.

Nitrous oxide in the headspace was analyzed using a gas chromatograph (Model 2010; Shimadzu Corp., Japan) fitted with an electron capture detector and Poropak Q column (1/8" SS column, $3.05 \mathrm{~m}$ length, 80/100 mesh; Chromatopak Analytical Instrumentation, India). The oven and detector temperatures were 40 and $300^{\circ} \mathrm{C}$ respectively. High purity nitrogen at a flow rate of $35 \mathrm{~mL} \mathrm{~min}^{-1}$ was used as a carrier gas. The gas chromatograph was calibrated using a secondary standard $44 \pm 0.38 \mathrm{nmol}$ 
$\mathrm{N}_{2} \mathrm{O}$ in $\mathrm{N}_{2}$ (National Physical Laboratory (NPL), New Delhi). The rate of $\mathrm{N}_{2} \mathrm{O}$ production was determined based on its linear accumulation over time (Tiedje, 1982). The Bunsen solubility coefficient for the measured salinity and temperature in the microcosms was used to correct for dissolved $\mathrm{N}_{2} \mathrm{O}$ (Weiss and Price, 1980). As the experiment was carried out in microcosms, it was necessary to minimize error likely to be caused by variability during sediment transfer. Hence, sediment used in each microcosm was filtered through a laboratory grade filter paper and dried at $60^{\circ} \mathrm{C}$ for approximately 48 hours. Average $\mathrm{N}_{2} \mathrm{O}$ production and DNT were calculated as nmol $\mathrm{N}_{2} \mathrm{O}-\mathrm{N} \mathrm{g}^{-1} \mathrm{~h}^{-1}$ of dry sediment.

Nitrous oxide produced through nitrification $\left({ }^{\mathrm{N}} \mathrm{N}_{2} \mathrm{O}\right)$ was calculated as:

${ }^{\mathrm{N}} \mathrm{N}_{2} \mathrm{O}=$ Net $\mathrm{N}_{2} \mathrm{O}$ production $-{ }^{\mathrm{D}} \mathrm{N}_{2} \mathrm{O}$

where,

Net $\mathrm{N}_{2} \mathrm{O}$ production $=\mathrm{N}_{2} \mathrm{O}$ production from denitrification plus nitrification (without nitrification inhibitor)

${ }^{\mathrm{D}} \mathrm{N}_{2} \mathrm{O}=\mathrm{N}_{2} \mathrm{O}$ produced by denitrifiers only (nitrification inhibited in presence of $10 \mathrm{~Pa} \mathrm{C}_{2} \mathrm{H}_{2}$ ) Percentage of $\mathrm{N}_{2} \mathrm{O}$ through incomplete denitrification $\left(\mathrm{N}_{2} \mathrm{O}\right)$ was calculated as:

$\%{ }^{\mathrm{I}} \mathrm{N}_{2} \mathrm{O}=\frac{{ }^{\mathrm{D}} \mathrm{N}_{2} \mathrm{O}}{\mathrm{DNT}} \times \frac{100}{1}$

where,

DNT $=$ Denitrification activity (in presence of $20 \mathrm{kPa} \mathrm{C}_{2} \mathrm{H}_{2}$ )

\section{Quantification of denitrifiers}

Denitrifiers were enumerated by the $\mathrm{N}_{2} \mathrm{O}$-most probable number (MPN) technique. The sediment core was thawed and sectioned at $2 \mathrm{~cm}$ intervals using a sterile core cutter to obtain representative samples at 0-2, 2-4, 4-6, 6-8 and 8-10 cm. Sediment from each depth was homogenised by mixing. Approximately $1 \mathrm{~g}$ of wet sediment was sub-sampled from each depth using sterile syringes. The sub-samples were transferred to $9 \mathrm{~mL}$ of sterile culture medium to give a $10^{-1}$ dilution. The culture medium was prepared as described by Michotey et al. (2000). Tween $80(20 \mu \mathrm{L})$ was added and the mixture was sonicated at $40 \mathrm{MHz}$ for 15 seconds. Serial dilutions for each section of the core were prepared in triplicates. The vials were purged with high purity $\mathrm{N}_{2}$ for 10 minutes to induce anaerobic conditions and supplemented with $20 \mathrm{kPa}$ acetylene (Bonin et al., 1994). The vials were incubated at room temperature in the dark for 10 days and the positive tubes were scored based on the accumulation of $\mathrm{N}_{2} \mathrm{O}$. Subsequent quantification 
was made using standard McCready's table (Rodina, 1972). Denitrifier abundance has been expressed as MPN cells $\mathrm{g}^{-1}$ of dry sediment.

\section{Statistical analyses}

All analyses were performed using Statistica version 6. Bacterial numbers were $\log _{10}$ transformed before analysis. Nitrous oxide production rates were checked for normal distribution using the Kolmogorov-Smirnov test. As the data was normally distributed $(p>0.2)$, t-Test was used to check for statistically significant differences in mean value of $\mathrm{N}_{2} \mathrm{O}$ production between the two sites. Pearson's correlation coefficients were used to assess relationships between biotic and abiotic parameters. The correlation values were plotted using Cytoscape 2.6.3 software which enabled an open-source network visualization. Principal component analysis (PCA) was used to examine the combined influence of environmental parameters on $\mathrm{N}_{2} \mathrm{O}$ production.

\section{Results}

\section{Physico-chemical characteristics}

The mangrove sediments were acidic in nature with $\mathrm{pH}$ ranging from 5.8-6.1 (Table 1). Sediment redox potentials were consistently low, in the range of $-27.8( \pm 0.9)$ to $-6( \pm 16.45) \mathrm{mV}$ at Tuvem while the Divar sediments exhibited the lowest redox potential of $-5.7( \pm 25.10)$ at a depth of 8-10 cm.

Pore water nutrient content varied widely with depth with $15.1( \pm 3.4) \mu \mathrm{mol} \mathrm{NH}{ }_{4}{ }^{-} \mathrm{N} \mathrm{L}^{-1}$ recorded at 8-10 cm depth at Tuvem, while $31.34( \pm 1.83)$ was recorded at Divar at a depth of 6-8 cm. Nitrite and nitrate concentration generally increased with depth with up to $11.7( \pm 0.8) \mu \mathrm{mol} \mathrm{NO}_{2}^{-}-\mathrm{N} \mathrm{L}^{-1}$ and 14.2 $( \pm 0.4) \mu \mathrm{mol} \mathrm{NO}_{3}^{-}-\mathrm{N} \mathrm{L}^{-1}$ respectively at Tuvem while at Divar the maximum levels were 14.2 $( \pm 0.0)$ $\mu \mathrm{mol} \mathrm{NO}{ }_{2}^{-}-\mathrm{N} \mathrm{L}^{-1} 10.1( \pm 0.2) \mu \mathrm{mol} \mathrm{N_{3 }}{ }^{-}-\mathrm{N} \mathrm{L}^{-1}$ at $6-8 \mathrm{~cm}$ depth respectively. Total organic carbon at Tuvem varied from 2.1-4.5\% while at Divar it ranged between $2.5-4.0 \%$.

\section{Denitrification \& net nitrous oxide production}

The profile of DNT at Tuvem, showed a maxima at 2-4 $\mathrm{cm}\left(2.23( \pm 0.34)\right.$ nmol $\left.\mathrm{N}_{2} \mathrm{O}-\mathrm{N} \mathrm{g}^{-1} \mathrm{~h}^{-1}\right)$ which decreased with depth (Fig. 2). Similarly at Divar, the highest DNT activity was observed within 0-4 cm and this was $\sim 5$ times higher than at Tuvem. 
Nitrous oxide production was significantly different (two-tailed t-test, $\mathrm{P}=0.003, \mathrm{n}=15$ ) at both the locations and varied with depth. At Tuvem, a steady decrease in $\mathrm{N}_{2} \mathrm{O}$ production with depth was observed. The highest production rate of $0.71( \pm 0.11) n$ mol $\mathrm{N}_{2} \mathrm{O}-\mathrm{N} \mathrm{g}^{-1} \mathrm{~h}^{-1}$ was recorded at $0-2 \mathrm{~cm}$ (Fig. $3)$. At the deepest layer investigated $(8-10 \mathrm{~cm})$, production of $\mathrm{N}_{2} \mathrm{O}$ had decreased to a minimum of 0.12 $( \pm 0.02)$ nmol $\mathrm{N}_{2} \mathrm{O}-\mathrm{N} \mathrm{g}^{-1} \mathrm{~h}^{-1}$. At Divar, the 2-4 $\mathrm{cm}$ layer had the maximum $\mathrm{N}_{2} \mathrm{O}$ production rate of 1.95 $( \pm 1.20)$ nmol $\mathrm{N}_{2} \mathrm{O}-\mathrm{N} \mathrm{g}^{-1} \mathrm{~h}^{-1}$. Depth integrated values for net $\mathrm{N}_{2} \mathrm{O}$ production and denitrification activity at both the locations are shown in Table 2.

\section{$\mathrm{N}_{2} \mathrm{O}$ production by denitrifiers}

Detailed investigations to elucidate the major pathway for $\mathrm{N}_{2} \mathrm{O}$ production at the relatively pristine site Tuvem showed that these sediments harbored up to $10^{7}$ denitrifiers $\mathrm{g}^{-1}$ sediment. Their abundance was maximum at 4-6 $\mathrm{cm}\left(7.14 \times 10^{7}\right.$ cells $\left.\mathrm{g}^{-1}\right)$ as compared to the other sections of the core where their number was relatively stable. In the Tuvem sediments, the denitrifiers significantly influenced $\mathrm{N}_{2} \mathrm{O}$ production $(n=15 ; r=0.55 ; p<0.05)$ as visualized in Fig. 4 . They also showed an inverse relationship with pore water $\mathrm{NH}_{4}{ }^{+}-\mathrm{N}(\mathrm{r}=-0.57 ; \mathrm{p}<0.05)$ and $\mathrm{NO}_{2}^{-}-\mathrm{N}(\mathrm{r}=-0.55 ; \mathrm{p}<0.05)$ concentrations.

In presence of a nitrification inhibitor, denitrifiers produced a maximum of $1.26( \pm 0.74) \mathrm{nmol}$ $\mathrm{N}_{2} \mathrm{O}-\mathrm{N} \mathrm{g}^{-1} \mathrm{~h}^{-1}$ at 0-2 cm (Fig. 5). Incomplete denitrification $\left({ }^{\mathrm{I}} \mathrm{N}_{2} \mathrm{O}\right.$ ) was responsible for 43-93\% (Fig. 6) of the $\mathrm{N}_{2} \mathrm{O}$ production which accounts for about 13-52\% (net $\mathrm{N}_{2} \mathrm{O} / \mathrm{DNT}^{*} 100$ ) of the $\mathrm{N}_{2} \mathrm{O}$ produced through denitrification. $\mathrm{N}_{2} \mathrm{O}$ production through nitrification $\left({ }^{\mathrm{N}} \mathrm{N}_{2} \mathrm{O}\right)$ was below detection.

\section{Environmental factors influencing $\mathrm{N}_{2} \mathrm{O}$ production}

Relationships of $\mathrm{N}_{2} \mathrm{O}$ production rates with physico-chemical parameters at Tuvem showed an inverse relationship between $\mathrm{N}_{2} \mathrm{O}$ production and pore water $\mathrm{NO}_{2}^{-}-\mathrm{N}$ concentration $(n=15 ; \mathrm{r}=-0.47$; $\mathrm{p}<0.05)$. Up to $32 \%$ of the variation in $\mathrm{N}_{2} \mathrm{O}$ production was negatively influenced by sediment $\mathrm{pH}(\mathrm{r}=-$ $0.57 ; \mathrm{p}<0.05$ ). Even though the relationship between $\mathrm{N}_{2} \mathrm{O}$ concentration and total organic carbon was not statistically significant, a positive relationship existed between these parameters.

Principal component analysis (PCA) on sediment variables resulted in four main components explaining nearly $80 \%$ of the total variance (Table 3) in $\mathrm{N}_{2} \mathrm{O}$ production. The first component in the correlation plot explained $29 \%$ of the observed variance. A forward regression (Fig. 7) of the reductive processes in the $\mathrm{N}$ cycle (DNT and $\mathrm{N}_{2} \mathrm{O}$ production) was observed in the first component. Sediment $\mathrm{pH}$, 
denitrifier abundance and $\mathrm{NO}_{2}^{-}-\mathrm{N}$ significantly influenced this component. The second component explained $22 \%$ of the variance with pore water $\mathrm{NO}_{3}{ }^{-} \mathrm{N}$ and organic carbon concentrations correlating strongly with this component. The third component correlated with pore water $\mathrm{NH}_{4}{ }^{+}-\mathrm{N}$ and denitrification activity and explained $16 \%$ of the variation. The only and most significant variable in the fourth component was sediment redox potential which explained $12 \%$ of the variation.

\section{Discussion}

The Mandovi estuary receives a considerable nutrient input from various sources such as mining wastes (De Sousa, 1983; De Sousa, 1999), land runoff during the summer monsoon (Sardessai and Sundar, 2007; Divya et al., 2009), remineralization of organic matter (Pratihary et al., 2009), sewage effluents (Ansari et al., 1986), etc. Hence we expected the adjoining Divar mangrove ecosystem fringing the estuary to also contain elevated inorganic $\mathrm{N}$ levels favouring denitrification and consequently $\mathrm{N}_{2} \mathrm{O}$ production. As hypothesized, down-core DNT at Divar was found to be comparatively higher than at the relatively pristine site Tuvem (Fig. 2). Low redox potentials $(<115 \mathrm{mV})$ at the sampling sites (Table 1) are indicative of anaerobic conditions in the sediment which are conducive for alternate respiratory pathways like denitrification and sulfate reduction. Pore water profiles in the present study revealed that low $\mathrm{NO}_{3}{ }^{-} \mathrm{N}$ concentrations within 0-4 $\mathrm{cm}$ layer in the Divar sediments coincided with elevated DNT. Denitrification is dependent on $\mathrm{NO}_{3}{ }^{-}-\mathrm{N}$ supply either from nitrification (Klingensmith and Alexander, 1983) or availability of the nutrient from the ambient seawater. The surficial sediments especially, are continuously replenished with nutrients from the estuarine water. These sediments $(\leq 4 \mathrm{~cm})$ act as efficient traps to immobilize nutrients (Tam and Wong, 1993) which consequently enhances $\mathrm{N}$ metabolism within this depth range. Our observation is consistent with earlier studies by Jørgensen (1989) who has shown that the denitrification capacity of estuarine sediments was always highest at the surface and declined with depth. To compare DNT measured using the acetylene block technique in the present study with other similar measurements in mangrove ecosystems, values were integrated to $10 \mathrm{~cm}$ depth. Denitrification occurred at a rate of up to $0.67 \mathrm{mmol} \mathrm{N}_{2} \mathrm{O}-\mathrm{N} \mathrm{m}^{-2} \mathrm{~h}^{-1}$ in the sediments examined (Table 2). These values are similar in range to those reported from a mangrove system prone to secondary sewage effluents (Corredor and Morell, 1994) and in other estuaries (Barnes and Owens, 1998; Bernot et al., 2003). Though over-enrichment of nutrients in coastal waters has ecological implications (Howarth et al., 2000), very little is known about the fate of terrestrially-derived nutrients in the Mandovi estuarine system. Pratihary et al., (2009) state that benthic denitrification is responsible 
for $22 \%$ removal of riverine dissolved inorganic $\mathrm{N}$ in the Mandovi estuary. The high denitrifying capacity of the Divar sediments suggests that this ecosystem also acts as a buffer zone by reducing nutrient levels through the denitrification process and helps to maintain the water quality of the adjoining estuary.

High DNT at Divar was accompanied by elevated $\mathrm{N}_{2} \mathrm{O}$ production (Fig. 3) as compared to Tuvem. Net $\mathrm{N}_{2} \mathrm{O}$ production at Divar occurred at a rate of up to $1.95 \mathrm{nmol} \mathrm{g}^{-1} \mathrm{~h}^{-1}$ which is almost three times higher than the relatively pristine site Tuvem. Natural $\mathrm{N}_{2} \mathrm{O}$ production rates in estuarine sediments range from 0.1 to $8.5 \mu \mathrm{mol} \mathrm{m} \mathrm{m}^{-2} \mathrm{~h}^{-1}$ (Wang et al., 2007). At $\mathrm{NO}_{3}{ }^{-}-\mathrm{N}$ concentrations of $\sim 10-15 \mu \mathrm{mol}$ (in situ + ambient seawater used in medium), depth integrated $\mathrm{N}_{2} \mathrm{O}$ production values of up to $0.1 \mathrm{mmol}$ $\mathrm{N}_{2} \mathrm{O}-\mathrm{N} \mathrm{m}^{-2} \mathrm{~h}^{-1}$ (Table 2) recorded in our study are far greater than those reported by Dong et al. (2002) from the anthropogenically influenced Colne estuary at similar $\mathrm{NO}_{3}{ }^{-}$concentration. A microsensor approach by Meyer et al. (2008) has shown that in sub-tropical mangrove sediments, anaerobic $\mathrm{N}_{2} \mathrm{O}$ production (through denitrification) under eutrophicated conditions occurs at a rate of $0.1 \mathrm{mmol} \mathrm{m}^{-2} \mathrm{~h}^{-1}$. These values are comparable to those recorded in the current study. Our findings emphasize that ecosystems prone to higher $\mathrm{N}$ loading can have a detrimental effect on the environment through increased $\mathrm{N}_{2} \mathrm{O}$ production. Elevated levels of greenhouse gas emissions from these sediments would thus pose a major environmental issue.

Experiments to examine the major pathway for $\mathrm{N}_{2} \mathrm{O}$ production in the present study indicates that up to $93 \%$ incomplete denitrification at the surface of mangrove sediments (Fig. 6) could contribute substantially to an increase in atmospheric $\mathrm{N}_{2} \mathrm{O}$. Studies by Robinson et al. (1998) in hypernutrified estuarine sediments have also shown higher $\mathrm{N}_{2} \mathrm{O}$ concentrations in the surface layer $(\leq 2 \mathrm{~cm})$ attributing it to denitrification fuelled by $\mathrm{NO}_{3}{ }^{-}-\mathrm{N}$ availability. Similarly, Koike and Terauchi (1996) also reported their highest concentration of $\mathrm{N}_{2} \mathrm{O}$ in the top $1 \mathrm{~cm}$ of the marine sediments studied. Stratified sampling in our study showed that benthic $\mathrm{N}_{2} \mathrm{O}$ production was found to generally decrease with depth. The flux of the radiative gas to the atmosphere would however be dependent on the diffusion coefficient and $\mathrm{N}_{2} \mathrm{O}$ consumption rates in the sediment layers it passes through.

A number of factors are known to influence the production of $\mathrm{N}_{2} \mathrm{O}$ in marine sediments. Physical, chemical, biological and environmental factors like temperature, $\mathrm{pH}$, sediment redox potential (Van Cleemput and Samater, 1996), organic C availability (Rosswell et al., 1989), $\mathrm{NO}_{2}{ }^{-}-\mathrm{N}$ concentration 
(Dong et al., 2002) and denitrifying communities play an important role in $\mathrm{N}_{2} \mathrm{O}$ production. Statistical analysis showed that pore water nutrient concentrations, organic carbon availability and denitrifiers were some of the important factors influencing the production of $\mathrm{N}_{2} \mathrm{O}$ in the current study. Degradation of sediment organic matter results in acidic conditions. Although the relationship between $\mathrm{N}_{2} \mathrm{O}$ production and total organic carbon content in these sediments was not significant, a positive relationship existed and is thus indicative of its influence on the gas. Though the water soluble fraction of organic $\mathrm{C}$ was not estimated during the study, it is possible that it stimulated denitrifier activity and consequently $\mathrm{N}_{2} \mathrm{O}$ production. Both denitrification rate and $\mathrm{N}_{2} \mathrm{O}$ production followed a decreasing trend with depth, however no significant relationship was observed between the two parameters. The production of $\mathrm{N}_{2} \mathrm{O}$ could be thus be governed by the availability of electron donors and acceptors like $\mathrm{NH}_{4}{ }^{+}, \mathrm{NO}_{3}{ }^{-}$, organic carbon rather than the rate of denitrification (Usui et al., 2001; Mathieu et al., 2006).

The denitrifier community was also found to influence $\mathrm{N}_{2} \mathrm{O}$ production in mangrove sediments (Figs. 4, 5). They numbered up to $10^{7}$ cells $\mathrm{g}^{-1}$ and their abundance could be regulated by the amount of organic matter available for their growth (Fig. 7). This can be easily explained by the fact that the denitrifiers are facultative aerobic microorganisms and their activity is limited by the amount of $\mathrm{NO}_{3}{ }^{-} \mathrm{N}$ available. Estuaries are generally heterotrophic systems, with bacterial respiration exceeding primary production (Heip et al., 1995, Gattuso et al., 1998). Consequently, removal of dissolved inorganic N from estuaries occurs through sedimentary denitrification and/or burial in the sediment (Middelburg and Nieuwenhuize, 2000). An inverse relationship observed between denitrifiers and pore water nutrient concentrations in the present study suggests that denitrification could play an important role in mitigating excess nutrients within the aquatic system preventing eutrophication.

In sulfidic sediments, the denitrification end product is known to shift from $\mathrm{N}_{2}$ to partially reduced inorganic $\mathrm{N}$ forms such as $\mathrm{NO}_{2}{ }^{-}$and $\mathrm{N}_{2} \mathrm{O}$ (Ebrahimipour et al., 2000). This could explain the high $\mathrm{NO}_{2}^{-}-\mathrm{N}$ pool in the largely anaerobic mangrove sediments studied. About $22 \%$ variation in $\mathrm{N}_{2} \mathrm{O}$ production was caused by the variation in $\mathrm{NO}_{2}{ }^{-} \mathrm{N}$ concentrations suggesting that it was one of the important and statistically significant parameters regulating the production of $\mathrm{N}_{2} \mathrm{O}$ in mangrove sediments. Many other studies have shown a correlation to exist between $\mathrm{N}_{2} \mathrm{O}$ production and $\mathrm{NO}_{2}{ }^{-}-\mathrm{N}$ concentration (He et al., 2001; Dong et al., 2004; Alinsafi et al., 2008). Denitrification activity in estuarine sediments is dependent on $\mathrm{NO}_{3}{ }^{-} \mathrm{N}$ availability (Kana et al., 1998) consequently leading to $\mathrm{NO}_{2}^{-}$and $\mathrm{N}_{2} \mathrm{O}$ production. Dong et al. (2002) state that formation of $\mathrm{N}_{2} \mathrm{O}$ from $\mathrm{NO}_{2}^{-}-\mathrm{N}$ is 
thermodynamically favourable compared to nitrate suggesting that it may be a critical factor regulating $\mathrm{N}_{2} \mathrm{O}$ formation. Bauza et al. (2002) have reported $\mathrm{N}_{2} \mathrm{O}$ production mainly through nitrification in red mangrove forests which are characterized by oxic conditions (redox potentials: $159-377 \mathrm{mV}$ ) and $\mathrm{NH}_{4}{ }^{+}-$ $\mathrm{N}$ concentrations varying from $0.188-0.273 \mathrm{mmol} \mathrm{L}^{-1}$. On the contrary, (Meyer et al., 2008) have shown that nitrification and denitrification contributed almost equally to $\mathrm{N}_{2} \mathrm{O}$ production under $\mathrm{NH}_{4}{ }^{+}$ammended conditions. In the present study, though ammonium concentrations at Tuvem were $<15 \mu$ mol $\mathrm{L}^{-1}$, it did not appear to assert a strong influence on $\mathrm{N}_{2} \mathrm{O}$ production. Nitrification could be a significant source of $\mathrm{N}_{2} \mathrm{O}$. In organically rich mangrove sediments, $\mathrm{NH}_{4}{ }^{+}-\mathrm{N}$ released through re-mineralization of organic matter could easily get bound to clay particles making it unavailable for biological uptake. Thus, when $\mathrm{NO}_{3}^{-}-\mathrm{N}$ and $\mathrm{NO}_{2}^{-}-\mathrm{N}$ pre-dominate, $\mathrm{N}_{2} \mathrm{O}$ arises from microbial denitrification (Corredor et al., 1999). Nitrate respiration is kinetically and thermodynamically favorable (Aivasidis et al., 2005) in oxygen depleted environments and is preferred over other electron acceptors (Canfield et al., 2005). Denitrification activity also enhances $\mathrm{NO}_{2}^{-}$uptake preventing its accumulation to toxic levels. Experimental results reveal that denitrification was the major pathway for $\mathrm{N}_{2} \mathrm{O}$ production in the mangrove ecosystems of Goa, India. Close grid measurements at sub-millimeter intervals by Meyer et al., (2008) have shown that in sub-tropical mangrove sediments, $\mathrm{N}_{2} \mathrm{O}$ production through nitrification occurs very close to the surface while denitrification is responsible for its production in the deeper anaerobic layers. The production of $\mathrm{N}_{2} \mathrm{O}$ through nitrification could be more prominent when the oxidative process is more pronounced. However, $\mathrm{N}_{2} \mathrm{O}$ production through nitrification was not detected indicating that the reductive phase of the $\mathrm{N}$ cycle was pre-dominant at the time of sampling (postmonsoon). Despite denitrification showing highest activity during the pre-monsoon season (data not shown), measurements have shown that the mechanism of $\mathrm{N}_{2} \mathrm{O}$ production in mangrove sediments of Goa during all the three seasons is essentially the same.

\section{Conclusion}

Denitrification and $\mathrm{N}_{2} \mathrm{O}$ producing capacity of anthropogenically influenced mangrove ecosystems was clearly higher when compared to relatively pristine locations. $\mathrm{N}_{2} \mathrm{O}$ production in the mangrove sediments of Goa was associated mainly with denitrification whereas its production through nitrification was non-detectable. The highest percentage of $\mathrm{N}_{2} \mathrm{O}$ production through incomplete denitrification occurred within the first two centimetres of the sediment, a fraction of which could be lost to the atmosphere. Nitrite concentration and denitrifier abundance were the two most important environmental 
parameters governing the production of $\mathrm{N}_{2} \mathrm{O}$ in these sediments indicative of active nutrient uptake by the autochthonous denitrifier community. Though mangroves have the ability to efficiently moderate elevated nutrient concentrations in the estuarine system through the denitrification pathway, they also pose a threat by increasing greenhouse gas production. Our study shows that in mangroves prone to elevated nutrient levels, benthic $\mathrm{N}_{2} \mathrm{O}$ production was three orders higher than natural production rates in estuarine sediments elsewhere. Thus, adequate measures like lowering use of $\mathrm{NH}_{4} \mathrm{NO}_{3}$ in mining activities and building predictive models (Valiela et al., 2000, 2004; Bowen et al., 2007) for tracking the fate of $\mathrm{N}$ inputs could be initiated to minimize $\mathrm{N}$ loading in adjoining estuarine systems. These strategies would not only help to lower $\mathrm{N}$ pollution but also simultaneously result in decreased $\mathrm{N}_{2} \mathrm{O}$ emission to the atmosphere.

\section{Acknowledgements}

The authors thank Dr. S.R. Shetye, Director, NIO for the facilities. Sheryl is grateful to the Council of Scientific and Industrial Research (Govt. of India) for the award of Senior Research Fellowship and to the Embassy of France in India for the award of Sandwich PhD Scholarship. The authors are thankful to Dr. Wajih Naqvi (NIO) and his team for discussions at the initial stages of the experiment. Dr. Prabhat Gupta (NPL) is acknowledged for providing the $\mathrm{N}_{2} \mathrm{O}$ standard. We thank two anonymous reviewers for their critical and constructive review that helped us improve this manuscript. We are also grateful to Tim Clough, Technical Editor, JEQ for valuable suggestions. The authors appreciate the help of Mr. Santosh Shirodkar during field sampling. This is NIO contribution no. XXXX 


\section{References}

Aivasidis, A., P., Melidis, and D. Georgiou. 2005. Continuous denitrification by external electron-donor supply utilizing an algorithm-based software controller. Biochem. Eng. J. 25: 179-186.

Alinsafi, A., N. Adouani, F. Béline, T. Lendormi, L. Limousy, and O. Sire. 2008. Nitrite effect on nitrous oxide emission from denitrifying activated sludge. Process Biochem. 43(6): 683-689.

Alongi, D.M., K.G. Boto, and F. Tirendi. 1989. Effect of exported mangrove litter on bacterial productivity and dissolved organic carbon fluxes in adjacent tropical nearshore sediments. Mar. Ecol. Prog. Ser. 56: 133-144.

Alongi, D.M., K.G. Boto, and A.I. Robertson. 1992. Nitrogen and phosphorous cycles. p. 251-292. In A.I. Robertson, and D.M. Alongi (eds.) Tropical mangrove ecosystems. American Geophysical Union, Washington, DC.

Ansari Z.A., B.S. Ingole and Parulekar, A. H. 1986. Effect of high organic enrichment of benthic polychaete population in an estuary. Mar. Pollut. Bull. 17(8): 361-365.

Bange, H.W., S. Rapsomanikis, and M.O. Andreae. 1996. Nitrous oxide in coastal waters. Global Biogeochem. Cy. 10: 197-207.

Bange, H.W., M.O. Andreae, S. Lal, C.S. Law, S.W.A. Naqvi, P.K. Patra, T. Rixen, and R.C. UpstillGoddard. 2001. Nitrous oxide emissions from the Arabian Sea: A synthesis. Atmos. Chem. Phy. Discuss. 1: 61-71.

Barnes, J., and N.J.P. Owens. 1998. Denitrification and nitrous oxide concentrations in the Humber Estuary, UK, and adjacent coastal zones. Mar. Pollut. Bull. 37(3-7): 247-260.

Bauza, J.F., J.M. Morell, and J.E. Corredor. 2002. Biogeochemistry of nitrous oxide production in the red mangrove (Rhizophora mangle) forest sediments. Estuar. Coast. Shelf S. 55(5): 697-704.

Bendschneider, K., and N.J. Robinson. 1952. A new spectrophotometric determination of nitrite in seawater. J. Mar. Res. 11: 87-96.

Berg P., L. Klemedtsson, and T. Rosswall. 1982. Inhibitory effect of low partial pressures of acetylene on nitrification. Soil Biol. Biochem. 14(3): 301-303.

Bernot, M.J., W.K. Dodds, W.S. Gardner, M.J. McCarthy, D. Sobolev, and J.L. Tank. 2003. Comparing denitrification estimates for a Texas estuary by using acetylene inhibition and membrane inlet mass spectrometry. Appl. Environ. Microb. 69(10): 5950-5956.

Bonin, P., E.R. Ranaivoson, N. Raymond, A. Chalamet, and J.C. Bertrand. 1994. Evidence for denitrification in marine sediment highly contaminated by petroleum products. Mar. Pollut. Bull. 28: 89-95.

Bonin, P., C. Tamburini, and V. Michotey. 2002. Determination of bacterial processes which are sources of nitrous oxide production in marine samples. Water Res. 36: 722-732. 
Bowen, J.L., J.M. Ramstack, S. Mazzilli, and I. Valiela. 2007. NLOAD: An interactive, web-based modeling tool to predict nitrogen loads and concentrations in estuaries, and to explore options for nitrogen management. Ecol. Appl. 17:S17-S30.

Bremner, J.M., and A.M. Blackmer. 1978. Nitrous Oxide: Emission from soils during nitrification of fertilizer nitrogen. Science 199: 295-296.

Canfield, D.E., B., Thamdrup, and E. Kristensen. 2005. Aquatic geomicrobiology. Adv. Mar. Biol. 48: $1-600$.

Chiu, C.Y., S.C. Lee, T.H. Chen, and G. Tian. 2004. Denitrification associated N loss in mangrove soil. Nutr. Cycl. Agroecosys. 69: 185-189.

Corredor, J.E., and J.M. Morell. 1994. Nitrate depuration of secondary sewage effluents in mangrove sediments. Estuaries 17: 295-300.

Corredor, J.E., J.M. Morell, and J. Bauza. 1999. Atmospheric nitrous oxide fluxes from mangrove sediments. Mar. Pollut. Bull. 38(6): 473-478.

De Souza, S.N. 1983. Studies on the behaviour of nutrients in the Mandovi estuary during premonsoon. Estuar. Coast. Shelf S. 16: 299-308.

De Souza, S.N. 1999. Effect of mining rejects on the nutrient chemistry of Mandovi estuary, Goa. Indian J. Mar. Sci. 28: 198-210.

De Wilde, H.P.J., and M.J.M. De Bie. 2000. Nitrous oxide in the Schelde estuary: production by nitrification and emission to the atmosphere. Mar. Chem. 69: 203-216.

Divya B., S.O. Fernandes, G. Sheelu, S. Nair, P. A. Loka Bharathi, and D. Chandramohan. 2009. Limnotolerant bacteria govern nitrate concentration in Mandovi estuary, India. Estuar. Coast. Shelf S. 82: 29-34.

Dong, L.F., D.B. Nedwell, G.J.C. Underwood, D.C.O. Thornton, and I. Rusmana. 2002. Nitrous oxide formation in the Colne Estuary, England: The Central role of nitrite. Appl. Environ. Microb. 8: $1240-1249$.

Dong, L.F., D.B.Nedwell, I. Colbeck, and J. Finch. 2004. Nitrous Oxide Emission from some English and Welsh Rivers and Estuaries. Water, Air Soil Poll. 4(6): 127-134.

Ebrahimipour, G., P. Lindenlaub, and T. Höpner. 2000. Denitrification in intertidal black anoxic surface sediments forms rather $\mathrm{N}_{2} \mathrm{O}$ and nitrite instead of molecular nitrogen. Mar. Biodiversity 30(3-6): 73-80.

El Wakeel, S.K., and J.P. Riley. 1957. Determination of organic carbon in the marine muds. J. Du Conseil Intrenational Pour L'exploration De La Mer 22 : 180-183.

Firestone, M.K., and E.A. Davidson. 1989. Microbiological basis of NO and nitrous oxide production and consumption in soil. p. 7-21. In M.O. Andreae, and D.S. Schimel, (eds.) Exchange of trace gases between terrestrial ecosystems and the atmosphere. John Wiley \& Sons, New York. 
Forster, P., V. Ramaswamy, P. Artaxo, T. Berntsen, R. Betts, D.W. Fahey, J. Haywood, J. Lean, D.C. Lowe, G. Myhre, J. Nganga, R. Prinn, G. Raga, M. Schulz, and R. Van Dorland, 2007. Changes in atmospheric constituents and in radiative forcing. In Solomon, S., D. Qin, M. Manning, Z. Chen, M. Marquis, K.B. Averyt, M. Tignor, and H.L. Miller (eds.) Climate change 2007: The physical science basis. Contribution of working Group I to the fourth assessment report of the Intergovernmental Panel on Climate Change. Cambridge University Press, Cambridge, United Kingdom and New York, NY, USA.

Gattuso, J.P., M. Frankignoulle, and R. Wollast. 1998. Carbon and carbonate metabolism in coastal aquatic ecosystems. Annu. Rev. Ecol. S. 29: 405-434.

He, Y., Y. Inamori, M. Mizuochi, H. Kong, N. Iwami, and T. Sun. 2001. Nitrous oxide emissions from aerated composting of organic waste. Environ. Sci. Technol. 35(11): 2347-2351.

Heip, C.H.R., N.K. Goosen, P.M.J. Herman, J. Kromkamp, J.J. Middelburg, and K. Soetaert, 1995. Production and consumption of biological particles in temperate tidal estuaries. Oceanogr. Mar. Biol. 33: 1-150.

Houghton, J.T., L.G. Meira Filho, B.A. Callander, N. Harris, A. Kattenberg, and K. Maskell (eds) 1996. Climate Change, 1995: The science of climate change. p.572 Cambridge University Press, Cambridge.

Howarth, R.W., D. Anderson, J. Cloern, C. Elfring, C. Hopkinson, B. Lapointe, T. Malone, N. Marcus, K. McGlathery, A. Sharpley, and D. Walker. 2000. Nutrient pollution of coastal rivers, bays, and seas. Iss. Ecol. 7: 1-15.

IPCC, 2007: Summary for Policymakers. In S. Solomon, D. Qin, M. Manning, Z. Chen, M. Marquis, K.B. Averyt, M. Tignor and H.L. Miller (eds.) Climate Change 2007: The physical science basis. Contribution of working group I to the fourth assessment report of the Intergovernmental Panel on Climate Change. Cambridge University Press, Cambridge, United Kingdom and New York, NY, USA.

Jørgensen, K.S. 1989. Annual pattern of denitrification and nitrate aAmmonification in estuarine sediment. Appl. Environ. Microb. 55(7): 1841-1847.

Kana, T.M., M.B. Sullivan, J.C. Cornwell, and K.M. Groszkowski. 1998. Denitrification in estuarine sediments determined by membrane inlet mass spectrometry. Limnol. Oceanogr. 43(2): 334339.

Klingensmith, K.M., and V. Alexander. 1983. Sediment nitrification, denitrification, and nitrous oxide production in a deep Arctic lake. Appl. Environ. Microb. 46(5): 1084-1092.

Koike, I., and K. Terauchi. 1996. Fine scale distribution of nitrous oxide in marine sediments. Mar. Chem. 52: 185-193.

Koroleff, F. 1969. Direct determination of ammonia in natural waters as indophenol blue. ICES C.M. 1969/C: 9. Hydrol Commun p. 4.

Kreuzwieser, J., J. Buchholz, and H. Rennenberg. 2003. Emission of methane and nitrous oxide by Australian mangrove ecosystems. Plant Biol. 5: 423-431. 
Krishnan, K.P., S.O. Fernandes, G.S. Chandan, and P.A. Loka Bharathi. 2007. Bacterial contribution to mitigation of iron and manganese in mangrove sediments. Mar. Pollut. Bull. 54(9): 1427-1433.

Krishnan, K.P., and P.A. Loka Bharathi. 2009. Organic carbon and iron modulate nitrification rates in mangrove swamps of Goa, South west coast of India. Estuar. Coast. Shelf S. 84: 419-426.

Krithika, K., R. Purvaja, and R. Ramesh. 2008. Fluxes of methane and nitrous oxide from an Indian mangrove. Curr. Sci. 94(2): 218-224.

Mathieu, O., J. Lévêque, C. Hénault, M.J. Milloux, F. Bizouard, and F. Andreux. 2006. Emissions and spatial variability of $\mathrm{N}_{2} \mathrm{O}, \mathrm{N}_{2}$ and nitrous oxide mole fraction at the field scale, revealed with ${ }^{15} \mathrm{~N}$ isotopic techniques. Soil Biol. Biochem. 38(5): 941-951.

Meyer, R.L., D.E. Allen, and S. Schmidt. 2008. Nitrification and denitrification as sources of sediment nitrous oxide production: A microsensor approach. Mar. Chem. 110: 68-76.

Michotey, V.D., V. Méjean, and P.C. Bonin. 2000. Comparison of methods for quantification of cytochrome $c d_{1}$-denitrifying bacteria in environmental marine samples. Appl. Environ. Microb. 66(4): 1564-1571.

Middelburg, J.J., and J. Nieuwenhuize. 2000. Uptake of dissolved inorganic nitrogen in turbid, tidal estuaries. Mar. Ecol. Prog. Ser. 192: 79-88.

Muñoz-Hincapié, M., J.M. Morell, and J.E. Corredor. 2002. Increase of nitrous oxide flux to the atmosphere upon nitrogen addition to red mangroves sediments. Mar. Pollut. Bull. 44(10): 992996.

Naqvi, S.W.A., D.A. Jayakumar, P.V. Narvekar, H. Naik, V.V.S.S. Sarma, W. DeSouza, S. Joseph, and M.D. George. 2000. Increased marine production of $\mathrm{N}_{2} \mathrm{O}$ due to intensifying anoxia on the Indian continental shelf. Nature 408: 346-349.

Nogales, B., N.T. Kenneth, D.B. Nedwell, and A.M. Osborn. 2002. Detection and diversity of expressed denitrification genes in estuarine sediments after reverse transcription-PCR amplification from mRNA. Appl. Environ. Microb. 68(10): 5017-5025.

Pratihary A.K., S.W.A. Naqvi, H. Naik, B. R. Thorat, G. Narvenkar, B.R. Manjunatha, and V.P. Rao. 2009. Benthic flux in a tropical estuary and its role in the ecosystem. Estuar. Coast. Shelf S. 85(3): 387-398.

Robinson, A.D., D.B. Nedwell, R.M. Harrison, and B.G Ogilvie, 1998. Hypernutrified estuaries as sources of $\mathrm{N}_{2} \mathrm{O}$ emission to the atmosphere: the estuary of the River Colne, Essex, U.K. Mar. Ecol. Prog. Ser. 164: 59-71.

Rodina, A.G. 1972. Methods in aquatic microbiology. p. 269-291. University Park Press, Butterworths, Baltimore London.

Rosswell, T.F., D.B. Bak, R.J. Cicerone, R. Conrad, D.H. Ehhalt, M.K. Firestone, I.E. Galbally, V.F. Galchenko, P.M. Croffman, H. Rapen, W.S. Reeburg, and E. Sanhueza. 1989. What regulates production and consumption of trace gases between terrestrial ecosystems and the atmosphere. $\mathrm{p}$. 73-95. In M.O. Andreae, and D.S. Schimel (eds.) John Wiley and Sons Ltd, Chichester, U.K. 
Sardessai, S., and D. Sundar. 2007. Variability of nitrate and phosphate. p. 59-66. In Shetye, S.R., M. Dileep Kumar, and D. Shankar (eds.) The Mandovi and Zuari estuaries. National Institute of Oceanography, India.

Sørensen, J. 1978. Denitrification rates in marine sediment as measured by the acetylene inhibition technique. Appl. Environ. Microb. 36: 139-143.

Tam, N.F.Y., and Y.S. Wong. 1993. Retention of nutrients and heavy metals in mangrove sediment receiving wastewater of different strengths. Envir. Technol. 14: 719-729.

Thorsten, D., and L.R. José. 2001. Do mangroves rather than rivers provide nutrients to coastal environments south of the Amazon River? Evidence from long-term flux measurements. Mar. Pollut. Bull. 213: 67-77.

Tiedje, J.M. 1982. Denitrification. p. 1011-1026 In A.L. Page (ed.) Methods of Soil Analysis, part 2. Madison, WI: ASA-SSSA.

Usui, T., I. Koike, and N. Ogura. 2001. $\mathrm{N}_{2} \mathrm{O}$ production, nitrification and denitrification in an estuarine sediment. Estuar. Coast. Shelf S. 52 (6): 769-781.

Valiela, I., M. Geist, J. McClelland, and G. Tomasky. 2000. Nitrogen loading from watersheds to estuaries: Verification of the Waquoit Bay nitrogen loading model. Biogeochemistry 49:277293.

Valiela, I., S. Mazzilli, J.L. Bowen, K.D. Kroeger, M.L. Cole, G. Tomasky, and T. Isaji.2004. ELM, an estuarine nitrogen loading model: Formulation and verification of predicted concentrations of dissolved inorganic nitrogen. Water Air Soil Poll. 157:365-391.

Van Cleemput, O., and A.H. Samater. 1996. Nitrite in soils: accumulation and role in the formation of gaseous N Compounds. Fertil. Res. 45: 81-89.

Wang, D., Z. Chen, J. Wang, S. Xu, H.Yang, H. Chen, L.Yang, and L. Hu. 2007. Summer-time denitrification and nitrous oxide exchange in the intertidal zone of the Yangtze Estuary. Estuar. Coast. Shelf S. 73: 43-53.

Weiss, R.F., and B.A. Price. 1980. Nitrous oxide solubility in water and seawater. Mar. Chem. 8, 347359.

Wood, E.D., F.A.J. Armstrong, and F.A. Richards. 1967. Determination of nitrate in sea water by cadmium-copper reduction to nitrite. J. Mar. Biol. Assoc. UK 47: 23-31.

Yamagishi, H., M.B. Westley, B.N. Popp, S. Toyoda, N. Yoshida, S. Watanabe, K. Koba, and Y. Yamanaka. 2007. Role of nitrification and denitrification on the nitrous oxide cycle in the eastern tropical North Pacific and Gulf of California. J. Geophys. Res. - Biogeoscience 112, G02015, doi: $10.1029 / 2006 J G 000227$. 


\section{Legend to figures:}

Fig. 1: Location of sampling sites along the Chapora and Mandovi estuary

Fig. 2: Denitrification profile $( \pm \mathrm{SD})$ over depth at Tuvem and Divar

Fig. 3: Variation in net $\mathrm{N}_{2} \mathrm{O}$ production $( \pm \mathrm{SD})$ with depth from the Tuvem and Divar mangrove sediments

Fig. 4: A network visualization of factors influencing nitrous oxide production arranged based on the hierarchy of $r$ value denoted at each node. Significant correlations at 0.05 probability level $(\mathrm{n}=15)$ have been highlighted in grey

Fig. 5: Nitrous oxide production by denitrifiers under nitrification inhibited conditions at Tuvem

Fig. 6: Percentage of $\mathrm{N}_{2} \mathrm{O}$ produced through incomplete denitrification at Tuvem

Fig. 7: Correlation plot from standardized principal component analysis (PCA) on sediment variables. Variables DNT= denitrification rate, $\mathrm{TOC}=$ total organic carbon

\section{Legend to tables:}

Table 1: Variation in the average values of physico-chemical parameters $( \pm S D ; n=15)$ in the Tuvem and Divar mangrove sediments

Table 2: Depth integrated $(0-10 \mathrm{~cm})$ net $\mathrm{N}_{2} \mathrm{O}$ production and denitrification activity in the Tuvem and Divar mangrove sediments.

Table 3: Results of principal component analysis of sediment variables and $\mathrm{N}_{2} \mathrm{O}$ production 


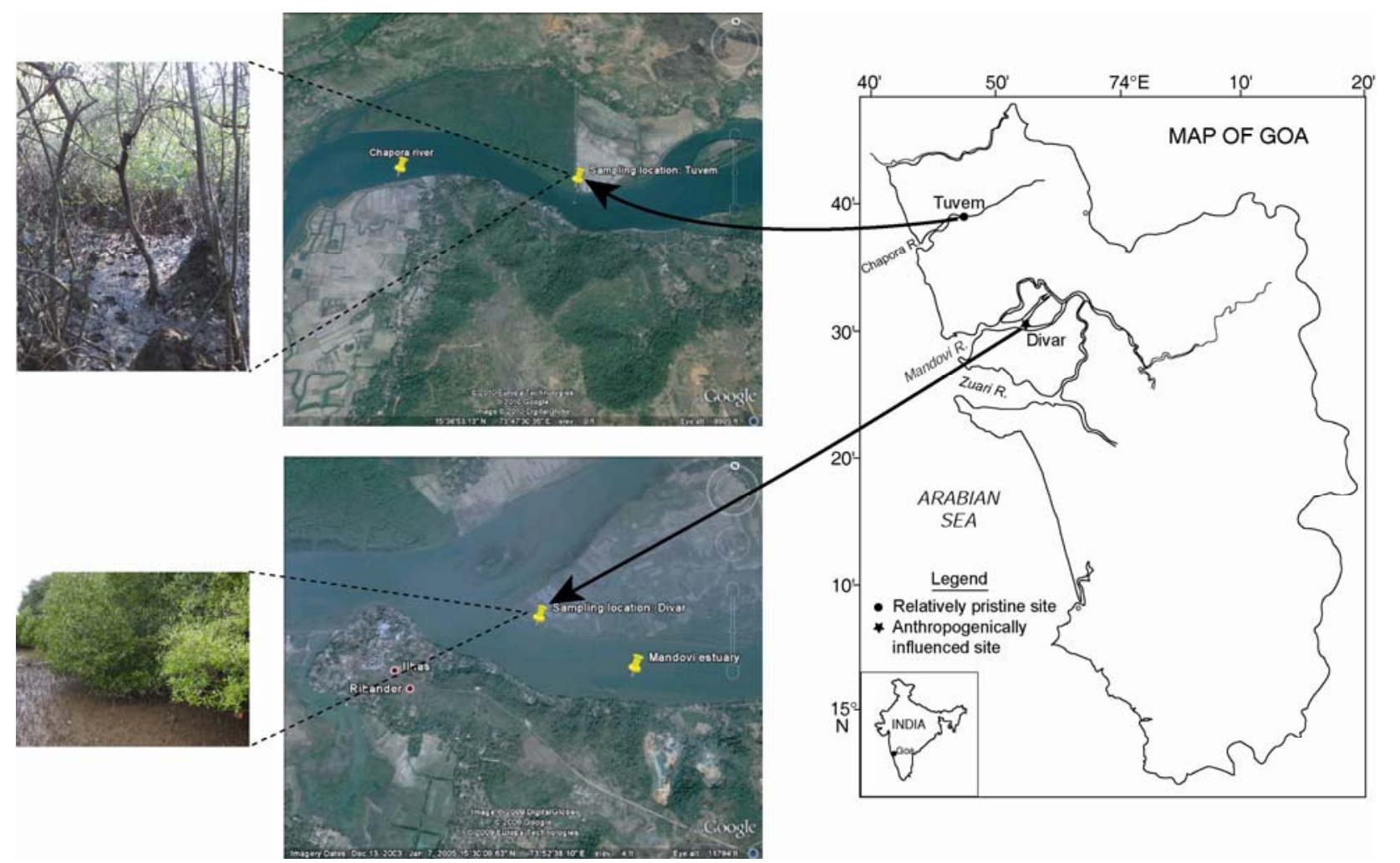

Fig. 1 


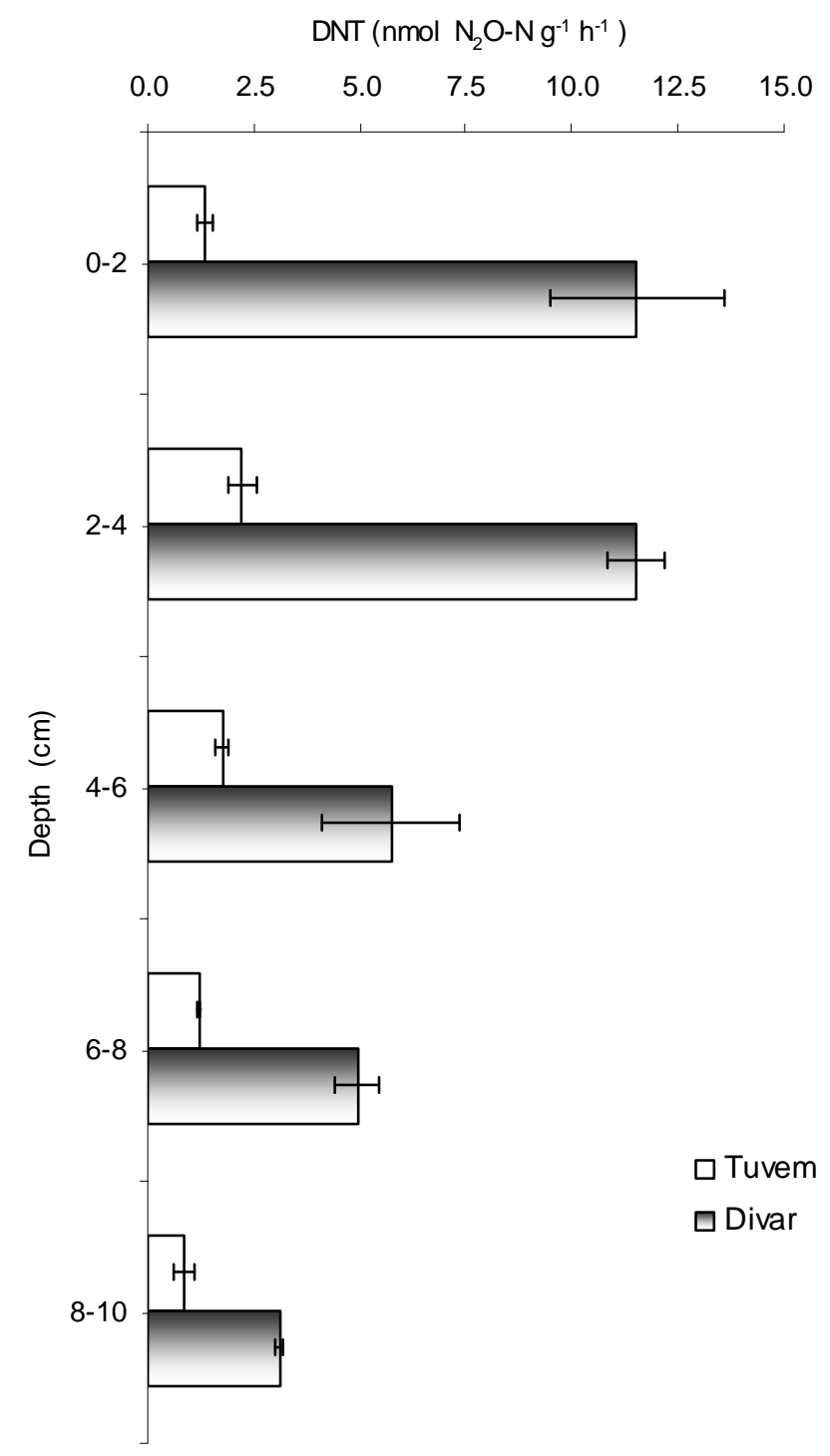

Fig. 2 


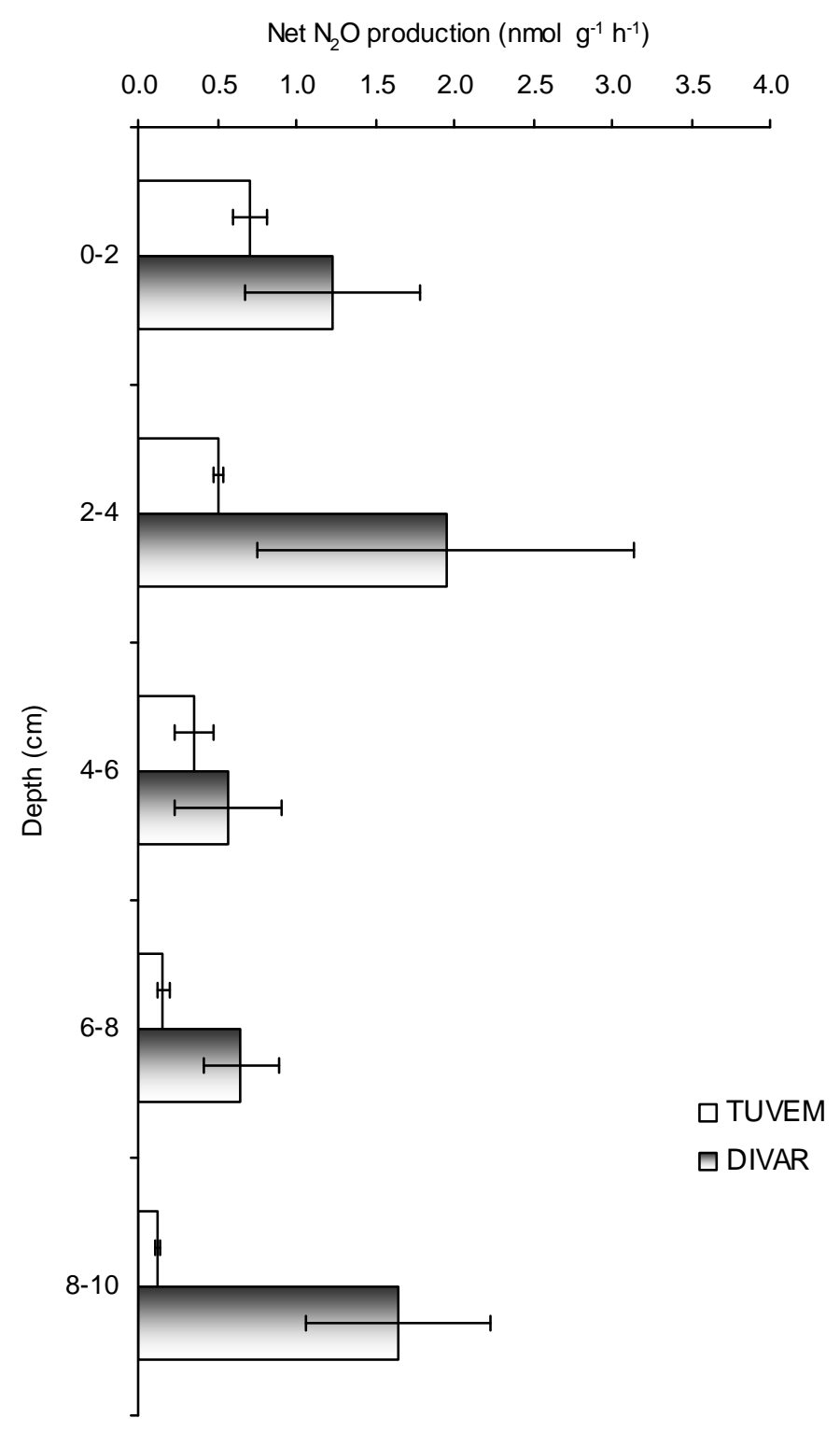

Fig. 3 


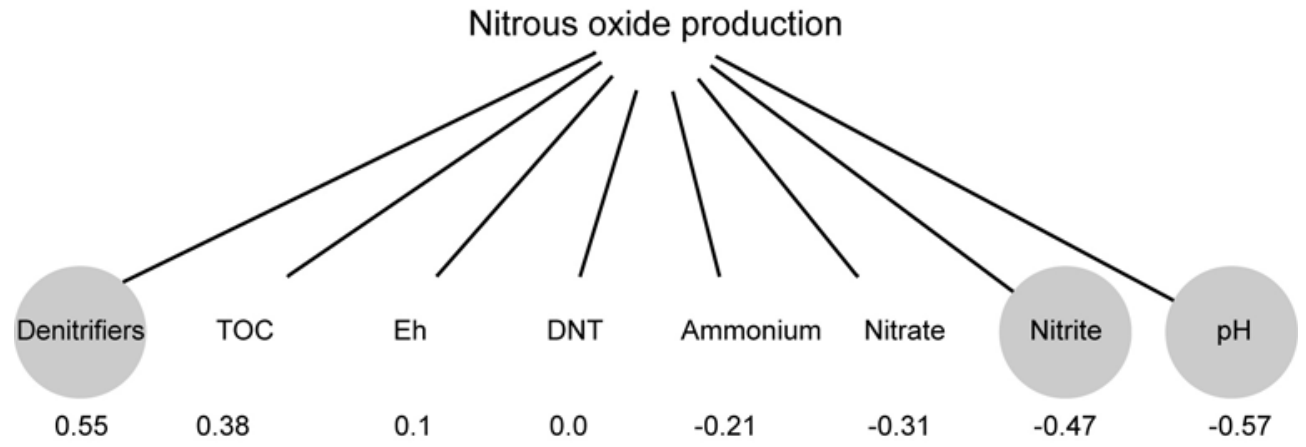

Fig. 4 


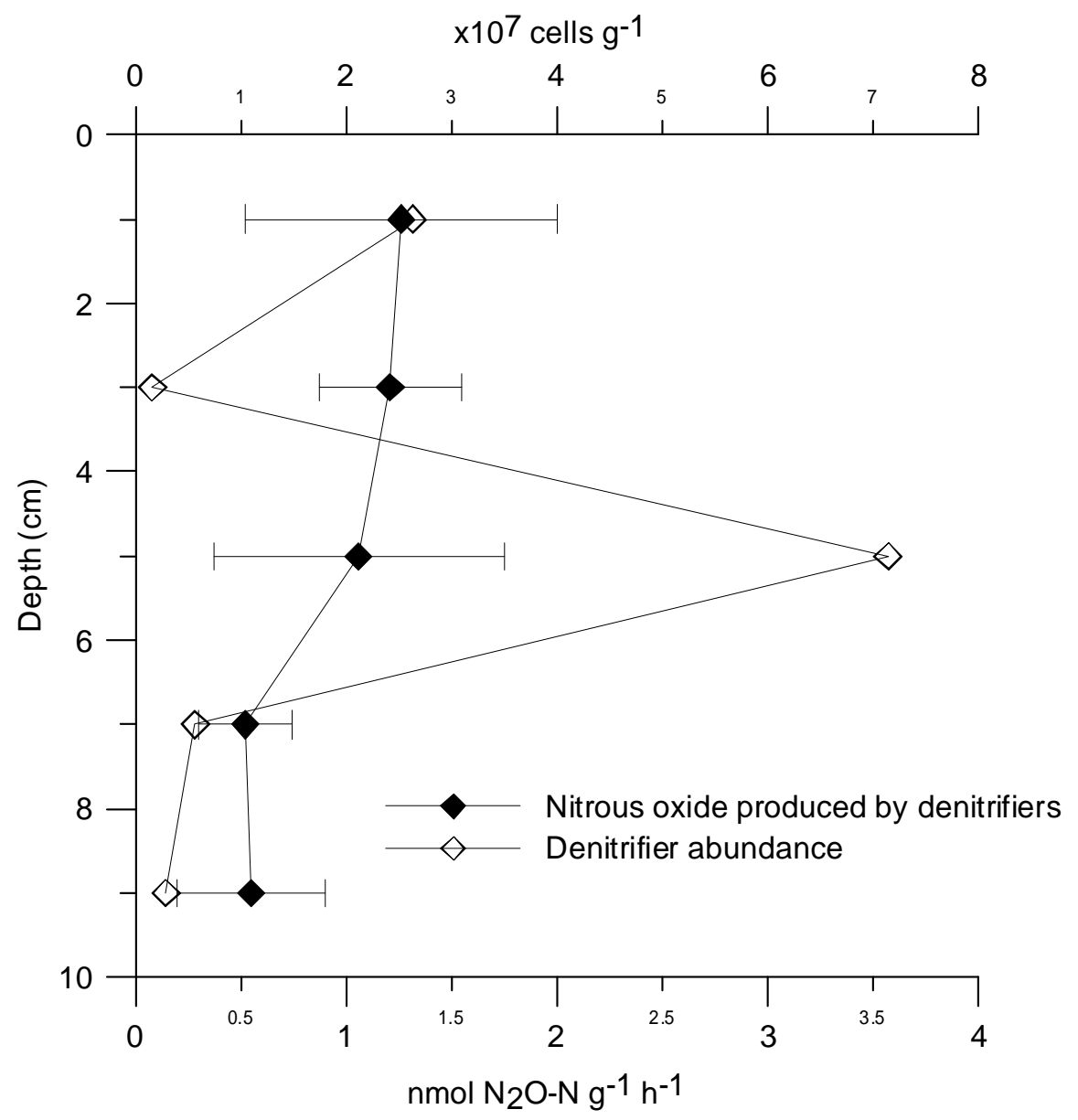

Fig.5 


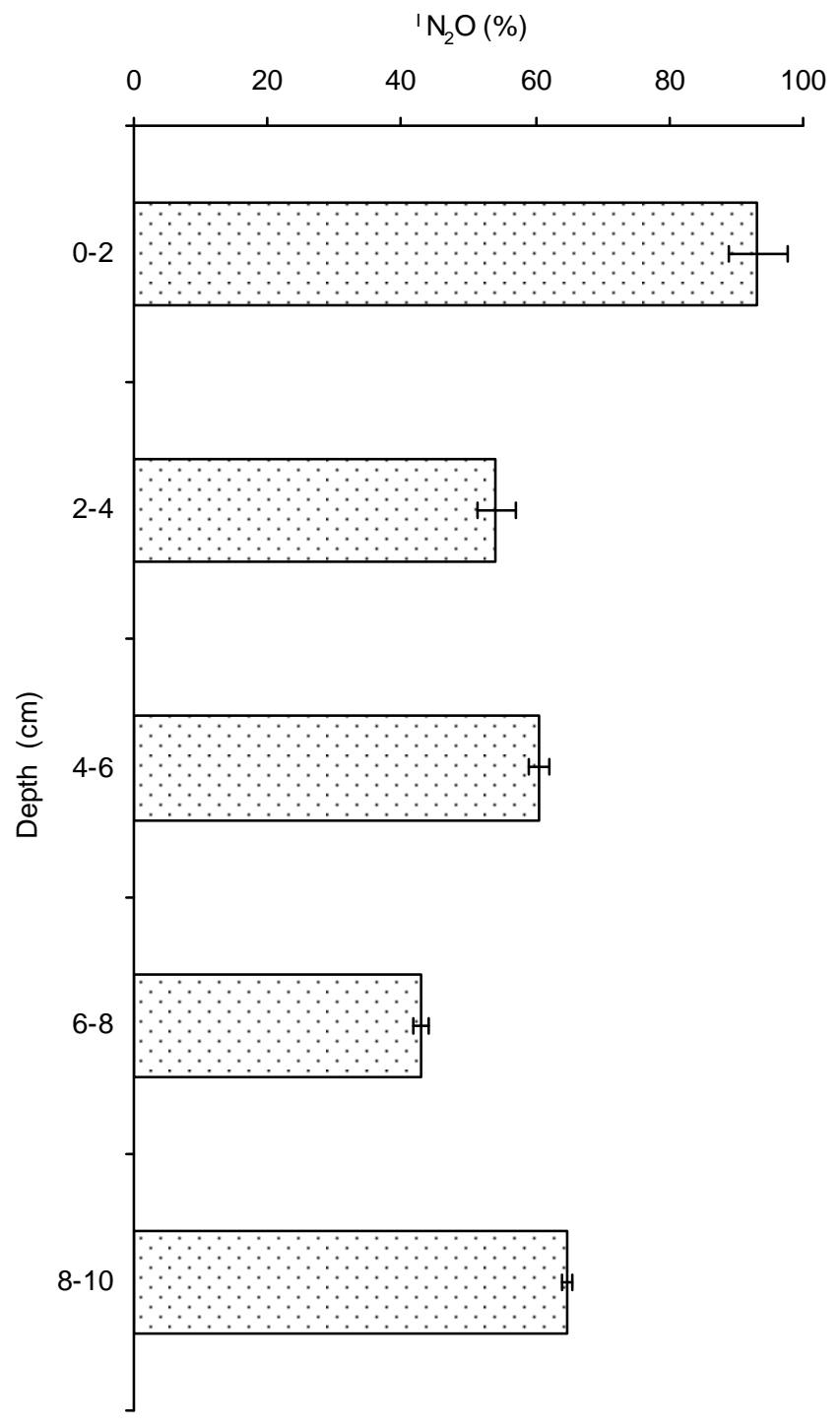

Fig.6 


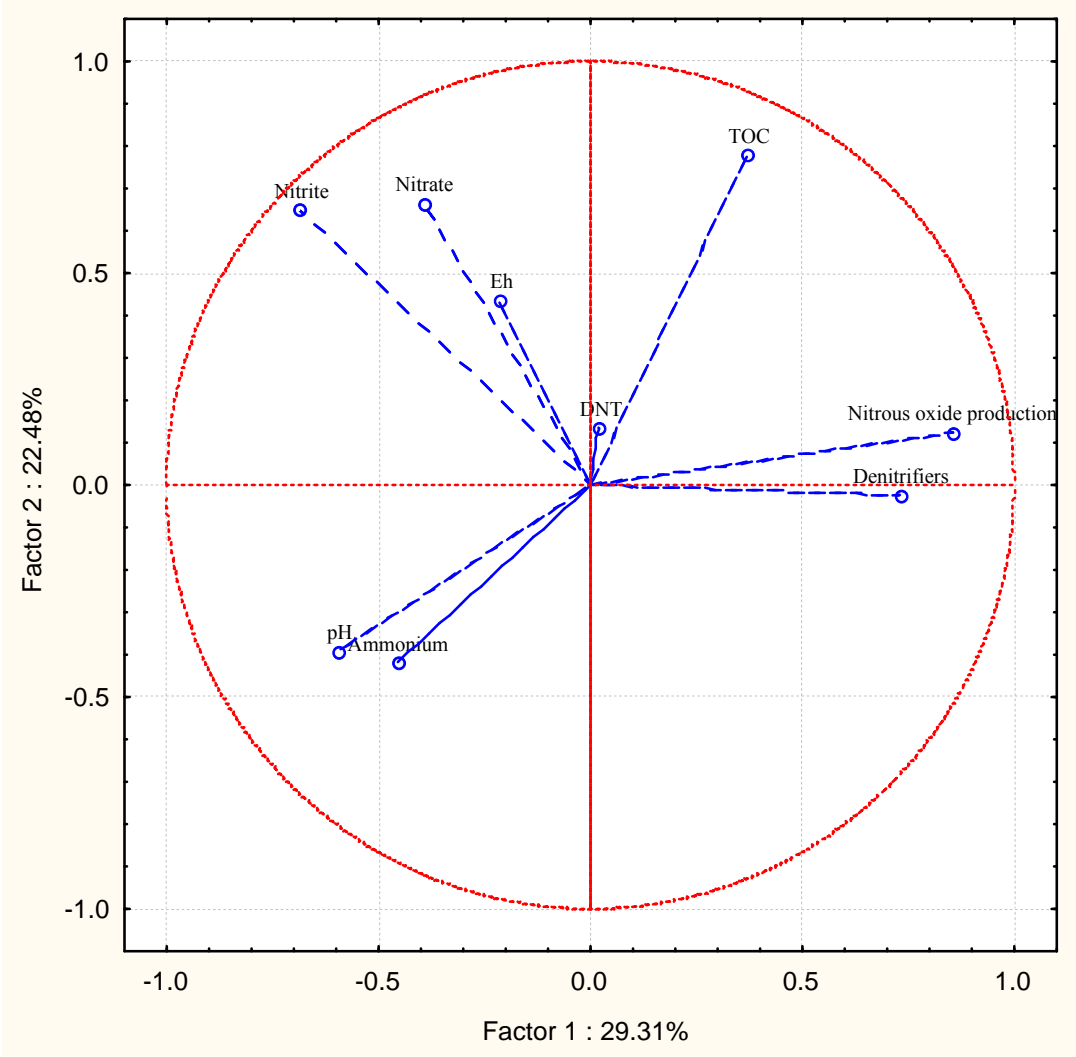

Fig. 7 
Table 1:

\begin{tabular}{|c|c|c|c|c|c|c|}
\hline \multicolumn{7}{|c|}{ Location: Tuvem } \\
\hline $\begin{array}{l}\text { Depth } \\
(\mathrm{cm})\end{array}$ & $\mathrm{pH}$ & $\begin{array}{c}\text { Eh } \\
(\mathrm{mV})\end{array}$ & $\begin{array}{c}\mathrm{NH}_{4}^{+}-\mathrm{N} \\
\left(\mu \mathrm{mol}{ }^{-1}\right)\end{array}$ & $\begin{array}{c}\mathrm{NO}_{2}^{-}-\mathrm{N} \\
\left(\mu \mathrm{mol} \mathrm{l}{ }^{-1}\right)\end{array}$ & $\begin{array}{c}\mathrm{NO}_{3}^{-}-\mathrm{N} \\
\left(\mu \mathrm{mol} \mathrm{l}^{-1}\right)\end{array}$ & $\begin{array}{c}\text { TOC } \\
(\%) \\
\end{array}$ \\
\hline $0-2$ & $5.8( \pm 0.2)$ & $-27.8( \pm 0.9)$ & $14.7( \pm 4.4)$ & $4.5( \pm 0.13)$ & $10.4( \pm 0.4)$ & $2.1( \pm 0.7)$ \\
\hline $2-4$ & $5.9( \pm 0.2)$ & $-23.2( \pm 7.39)$ & $15.0( \pm 1.4)$ & $8.6( \pm 0.33)$ & $9.9( \pm 0.4)$ & $2.9( \pm 1.4)$ \\
\hline $4-6$ & $6.0( \pm 0.6)$ & $-9.5( \pm 15.06)$ & $7.8( \pm 1.4)$ & $8.1( \pm 0.1)$ & $10.9( \pm 0.6)$ & $4.5( \pm 2.9)$ \\
\hline $6-8$ & $6.0( \pm 0.6)$ & $-6( \pm 16.45)$ & $12.0( \pm 0.8)$ & $10.9( \pm 0.6)$ & $14.2( \pm 0.4)$ & $4.4( \pm 2.8)$ \\
\hline $8-10$ & $6.1( \pm 0.5)$ & $-6.3( \pm 14.54)$ & $15.1( \pm 3.4)$ & $11.7( \pm 0.8)$ & $11.4( \pm 0.0)$ & $4.0( \pm 2.7)$ \\
\hline \multicolumn{7}{|c|}{ Location: Divar } \\
\hline $0-2$ & $5.9( \pm 0.3)$ & $115( \pm 64.7)$ & $15.7( \pm 3.4)$ & $7.2( \pm 0.0)$ & $4.6( \pm 0.7)$ & $2.9( \pm 1.6)$ \\
\hline $2-4$ & $5.8( \pm 0.1)$ & $94.3( \pm 62.6)$ & $15.1( \pm 2.0)$ & $4.1( \pm 0.2)$ & $4.2( \pm 0.2)$ & $4.0( \pm 2.1)$ \\
\hline $4-6$ & $5.1( \pm 0.1)$ & $93.5( \pm 45.18)$ & $23.8( \pm 2.3)$ & $6.6( \pm 0.6)$ & $9.3( \pm 0.2)$ & $2.5( \pm 1.0)$ \\
\hline $6-8$ & $6.0( \pm 0.1)$ & $50.8( \pm 61.38)$ & $31.3( \pm 1.8)$ & $14.2( \pm 0.1)$ & $10.1( \pm 0.2)$ & $3.3( \pm 1.7)$ \\
\hline $8-10$ & $6.0( \pm 0.0)$ & $-5.7( \pm 25.10)$ & $22.1( \pm 3.1)$ & $8.1( \pm 0.3)$ & $10.0( \pm 0.2)$ & $3.1( \pm 1.8)$ \\
\hline
\end{tabular}

Table 2:

\begin{tabular}{rrr}
\hline Depth integrated activity & Tuvem & Divar \\
\hline Denitrification $\left(\mathrm{mmol} \mathrm{N}_{2} \mathrm{O}-\mathrm{N} \mathrm{m}^{-2} \mathrm{~h}^{-1}\right)$ & 0.14 & 0.67 \\
Net $\mathrm{N}_{2} \mathrm{O}$ production $\left(\mathrm{mmol} \mathrm{N}_{2} \mathrm{O}-\mathrm{N} \mathrm{m}^{-2} \mathrm{~h}^{-1}\right)$ & 0.03 & 0.10 \\
\hline
\end{tabular}

Table 3:

\begin{tabular}{rrrrr}
\hline Variable & Component 1 & Component 2 & Component 3 & Component 4 \\
\hline $\mathrm{N}_{2} \mathrm{O}$ production & ${ }^{*} 0.856$ & 0.124 & 0.206 & 0.266 \\
$\mathrm{pH}$ & ${ }^{*}-0.597$ & -0.391 & -0.541 & 0.134 \\
$\mathrm{Eh}$ & -0.215 & 0.438 & 0.106 & ${ }^{*} 0.828$ \\
Ammonium & -0.453 & -0.420 & ${ }^{*} 0.640$ & 0.164 \\
Nitrite & ${ }^{*}-0.687$ & 0.649 & 0.093 & -0.004 \\
Nitrate & -0.395 & ${ }^{*} 0.665$ & -0.367 & 0.027 \\
Denitrifiers & $* 0.730$ & -0.023 & -0.496 & 0.326 \\
TOC & 0.369 & 0.779 & 0.286 & -0.330 \\
DNT & 0.021 & 0.133 & $*-0.487$ & -0.189 \\
Total variance $(\%)$ & 29.30 & 22.47 & 16.26 & 11.71 \\
\hline
\end{tabular}

${ }^{\dagger *}$ Correlation significant at 0.05 probability level; $\mathrm{TOC}=$ Total organic carbon, DNT=Denitrification rate 